
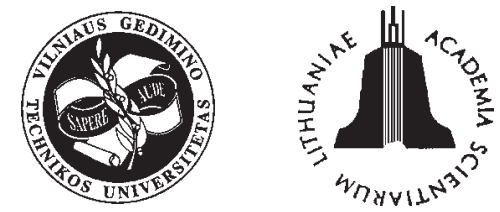

ISSN 1392-3730 print / ISSN 1822-3605 online

JOURNAL OF CIVIL ENGINEERING AND MANAGEMENT

http:/www.jcem.vgtu.lt

2006, Vol XII, No 1, 83-88

\title{
NEURAL MODEL OF RESIDENTIAL BUILDING AIR INFILTRATION PROCESS
}

\author{
Paweł Malinowski ${ }^{1}$, Iwona Polarczyk ${ }^{2}$, Jerzy Piotrowski ${ }^{3}$ \\ ${ }^{1,2}$ Technical University of Wroclaw, Institute of Air-Conditioning and District Heating, 4/6 Norwida Street, \\ 50-370 Wroclaw, Poland. E-mail: pawel.malinowski@pwr.wroc.pl \\ ${ }^{3}$ Świetokrzyski Technical University, Institute of Civil Engineering, 1000-lecia Street, 25-314 Kielce, Poland
}

Received 20 April 2005; accepted 21 Dec 2005

\begin{abstract}
For the needs of this paper, certain area of issues associated with the infiltration process and neural networks were selected. In the scope of infiltration process, the measurements and analysis of air infiltration through the buildings have shown how difficult this process is in terms of strict mathematical models formulation. In the scope of neural networks, attention was given to multi-layer perceptrons and systems composed of them. It must be noted that, due to the novelty of this method, a detailed description of the neuron network theory was presented in this paper as well as a thorough discussion of the neuron modelling process. The work was carried out in two stages, with the first stage covering the development of detailed methodology for the construction of neural model and the second stage in which a developed methodology was applied to modelling real objects.
\end{abstract}

Keywords: infiltration process, neural networks, neural models.

\section{Introduction}

Attractiveness of the neural networks in object modelling and identification applications results mostly from their ability to approximate any non-linearity and to adjust the accepted structure on the basis of experimental data or other training images. The subject-matter of the paper is neural networks being in the centre of interest of the modern science.

Analyses of factors affecting the magnitude and variation in time of air infiltration through the buildings have shown how difficult this process is in terms of strict mathematical formulation, being dependent on so many parameters which impact is not always evident and definable.

In order to achieve the stated objectives, the authors' efforts cover the following scope:

- development of methodology for neural model construction on the basis of measurement results,

- construction of air infiltration models with the help of neural network theory,

- verification of constructed models on the basis of monitoring,

- conclusions.

\section{Basics of neural network theory}

The most important feature of the neural networks is their ability to approximate any non-linearity. This offers the possibility of solving many non-linear problems that are difficult or insoluble by other methods. As there is no general and systematic theory for designing non-linear systems, attempts are made to build such a theory with the utilisation of neural network theory. The problem has been given attention in many publications [1-6].

\section{Modelling and identification of dynamic objects}

The problem of dynamic object modelling and identification is the key issue in many fields. The exact mathematical model description or ability to build its simulator with the use of any techniques creates, for example, the possibility to develop control systems that compared to the systems developed without that knowledge are much more effective $[7,8]$. Taking into account the great importance of these problems, hitherto existing theoretical and application studies have been conducted mostly in the area of mathematical modelling problems, and from the technical viewpoint in the area of methods for parametrical identification of various modelling structures $[9,10]$. The known developed methods refer mainly to static and dynamic linear objects, and non-linear problems are usually solved, due to their variety and complexity, with the use of various approximation methods and techniques $[7,11,12]$. 


\section{Methodology for construction of residential build- ing air infiltration neural model}

While an analysis of any problem with the use of conventional computer requires the formulation of a model, development of algorithm and its implementation in the form of a programme, the neural networks are able - with the use of proper, ,learning" schemes - to develop the proper model of a real phenomenon on the basis of data presented to them. In that sense, the neural network may be treated as a ,black box" with the only aim to react correctly to adequate input data: the internal organisation of such a mechanism is not only unknown but also non-essential. This means that a lot of burdensome and expensive work may be saved during the development of software, even though we actually know these rules. This does not means, however, that there is no work to be done. The issues that need solving are of different nature.

The basic problems faced during the modelling with the help of artificial neural networks include the following issues [13-15]:

a) issues concerning the model structure:

1. what input data describing the process are essential and should be used,

2. what should be the representation and scaling of these data;

b) issues concerning the architecture of neural network:

1. what learning algorithm should be used,

2. what is the optimal number of network's computational layers,

3. what is the optimal number of elements in particular layers,

4. what should be the activation function for a single neuron

5. how to select the way of presenting the input data,

6. what values of network's learning parameters should be selected.

If the above issues are properly solved, the resulting neural model will be correct. In the present stage of artificial neural network development, there is no formal procedure to deal with these problems, and it is usually based on modeller's experience gained from iterative trial-and-error method. The best network architecture is not known a priori but certain alternative of structures is arbitrary proposed and all variants of these structures are then tested in order to select the optimal structure from those proposed. Obviously, better structures that have not been taken into consideration may exist [16$18]$.

When selecting structures for the alternative, the experience of a person solving the problem is essential.

In the next part of this paper, the construction process of neural model for air infiltration phenomenon will be described. In reality, particular stages of the process are not separated so clearly as presented, but otherwise it would be difficult to discuss this process.
Measuring data were collected during measurements performed in typical for Poland 11-floor, 5-floor and 2floor residential buildings made from pre-cast units [19].

\section{Modelling variants}

The infiltration process was modelled in the following 6 different variants:

Variant 1. 11-floor version of the object, air exchange in room Variant 2. 5-floor version of the object, air exchange in room Variant 3. 2-floor version of the object, air exchange in room Variant 4. 11-floor version of the object, air exchange in flat Variant 5. 5-floor version of the object, air exchange in flat Variant 6. 2-floor version of the object, air exchange in flat

The division according to the building size proved to be indispensable in order to allow using the computer equipment in a way as simplified as possible.

\section{Characteristics of measuring data}

The data were collected from field measurement, the verification process was carried out in the framework of other research project [19], and verified data were stored in database where particular records include the following information:

r1: consecutive number of measuring data record

r2: symbol of object, according to key: object number, symbol of room (small, medium, large), symbol of flat (small, medium, large), symbol - onesided flat

$\mathrm{r} 3: \mathrm{T}_{\mathrm{dif}}-$ difference between external and internal temp $\left[{ }^{\circ} \mathrm{C}\right]$

$\mathrm{r} 4: \mathrm{V}_{\text {vent }}$ - wind velocity $[\mathrm{m} / \mathrm{s}]$

r5: $\mathrm{A}_{\text {wind }}-$ angle of wind arrival in relation to room wall $\left[^{\circ}\right]$

r6: $\mathrm{P}_{\text {dif }}$ - difference - external and internal pressure $[\mathrm{Pa}]$

r7: $H_{k} \quad-$ height of the whole object given as number of floors [non-dimensional]

r8: $\mathrm{L}_{\mathrm{k}} \quad$ - numb of floor of measurement [non-dimensional]

r9: $\mathrm{I}_{\text {gaps }}$ - quotient of total length of gaps in external woodwork and volume of room $\left[\mathrm{m} / \mathrm{m}^{3}\right]$

r10: $\mathrm{M}_{\text {room }}$ - room volume $\left[\mathrm{m}^{3}\right]$

r11: $\mathrm{W}_{\text {wood }}$ - coefficient of air permeability through external woodwork per range $\left[\mathrm{m}^{3} / \mathrm{m} . \mathrm{h} \mathrm{daPa}^{0,7}\right]$ :

$0.5: 0.5-0.8 ; 1.0: 0.9-1.2 ; 2.0: 1.8-2.4 ; 3.0: 2.7-3.2$

r12: $\mathrm{C}_{\text {room }}$ - the air exchange rate in room $\left[\mathrm{h}^{-1}\right]$

r13: $R_{r}$ - layout of rooms in flat (1 - facing in one direction, 2 - facing in two directions, etc) [non-dimensional]

r14: $\mathrm{N}_{\text {vent }}$ - number of ventilation ducts in flat [non-dimension]

r15: $I_{\text {gapfl }}$ - quotient of total length gaps in external woodwork and volume of flat $\left[\mathrm{m} / \mathrm{m}^{3}\right]$

r16: $\mathrm{M}_{\text {flat }}$ - volume of the whole flat $\left[\mathrm{m}^{3}\right]$

r17: $\mathrm{W}_{\text {gapfl }}$ - coefficient of air permeability through flat access door per range $\left[\mathrm{m}^{3} / \mathrm{m} . \mathrm{h} \mathrm{daPa}^{0,7}\right]: 2-2.0 ; 4-$ $3.5-4.5 ; 9-9.0-10.0$

r18: $\mathrm{C}_{\text {flat }}-$ the air change rate in a flat $\left[\mathrm{h}^{-1}\right]$ 


\section{Selection of network architecture}

In search of the network architecture, modelling work was based on the so-called "Crack method", and the following input data to the network were assumed:

- for neuron networks modelling the air change rate in a room:

v1: $A_{\text {wind }}-$ angle of wind arrival in relation to room wall $\left[^{\circ}\right]$

v2: $\mathrm{T}_{\text {dif }}-$ difference between external and internal temp $\left[{ }^{\circ} \mathrm{C}\right]$

v3: $\mathrm{V}_{\text {vent }}$ - wind velocity $[\mathrm{m} / \mathrm{s}]$

v4: $\mathrm{P}_{\text {dif }}$ - difference - external and internal pressure $[\mathrm{Pa}]$

v5: $L_{k}-$ numb of floor of measurement [non-dimensional]

v6: $I_{\text {gaps }}-$ quotient of total length of gaps in external woodwork and volume of room $\left[\mathrm{m} / \mathrm{m}^{3}\right]$

v7: $\mathrm{M}_{\text {room }}-$ room volume $\left[\mathrm{m}^{3}\right]$

v8: $\mathrm{W}_{\text {wood }}-$ coefficient of air permeability through external woodwork per range $\left[\mathrm{m}^{3} / \mathrm{m} . \mathrm{h} \mathrm{daPa}{ }^{0,7}\right]$ :

and the infiltration/exfiltration through gaps around internal doors where not modelled.

The air change rate in room was assumed as the process state variable and named as variable 9:

v9: $\mathrm{C}_{\text {room }}-$ air change rate in room $\left[\mathrm{h}^{-1}\right]$

- for neuron networks modelling the air change rate in a flat, first 5 variables were repeated the same as in a room model and next neurons are:

v6: $\mathrm{W}_{\text {wood }}-$ coefficient of air permeability through external woodwork per range $\left[\mathrm{m}^{3} / \mathrm{m} . h \mathrm{daPa}^{0,7}\right]$ :

v7: $R_{\mathrm{r}} \quad-$ layout of rooms in flat (1- facing in one direction, 2 - facing in two directions, etc) [non-dimensional]

v8: $\mathrm{N}_{\text {vent }}-$ number of ventilation ducts in flat [non-dimensional]

v9: $I_{\text {gapfl }}-$ quotient of total length of gaps in external woodwork and volume of flat $\left[\mathrm{m} / \mathrm{m}^{3}\right]$

v10: $\mathrm{M}_{\text {flat }}-$ volume of the whole flat $\left[\mathrm{m}^{3}\right]$

v11: $\mathrm{W}_{\text {gapfl }}-$ coefficient of air permeability through flat access door per range $\left[\mathrm{m}^{3} / \mathrm{m} . \mathrm{h} \mathrm{daPa}{ }^{0,7}\right]$

The air change rate in flat was assumed as process state variable and named variable 12 :

v12: $C_{\text {flat }}-$ the air change rate in flat $\left[\mathrm{h}^{-1}\right]$

The input data for training were coded in the form of vectors with elements standardised to the range $[0,1]$. As a result of the detailed study over selection of optimal architecture from the networks with one hidden layer of 4 neurons, the ultimately selected architecture is as follows:

1. for modelling of air change rate in a room, neural network with:

- 8 input neurons,

- 4 neurons of hidden layer

- 1 neuron of output layer.

Connection diagram of the above network may be illustrated as follows (Fig 1):

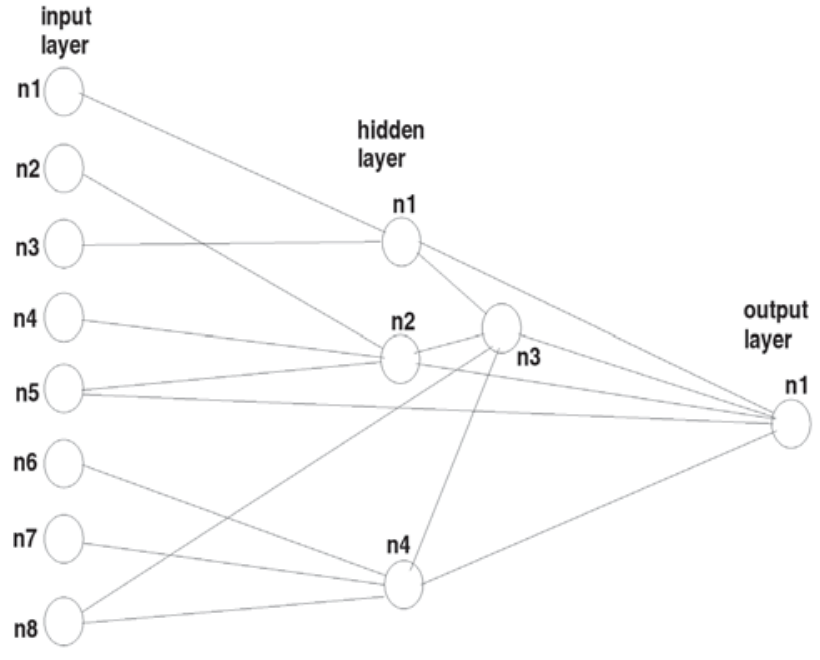

Fig 1. Connection diagram of neural networks for modelling the air change rate in room

where neurons in an input layer are:

n1: $A_{\text {wind }}$ - angle of wind arrival in relation to room wall $\left[^{\circ}\right]$

n2: $\mathrm{T}_{\text {dif }}-$ difference between external and internal temp $\left[{ }^{\circ} \mathrm{C}\right]$

n3: $\quad V_{\text {vent }}-$ wind velocity $[\mathrm{m} / \mathrm{s}]$

n4: $\mathrm{P}_{\text {dif }}$ - difference - external and internal pressure [Pa]

$n 5: \quad L_{k} \quad-$ numb of floor of measurement [non-dimensional]

n6: $I_{\text {gaps }}$ - quotient of total length of gaps in external woodwork and volume of room $\left[\mathrm{m} / \mathrm{m}^{3}\right]$

n7: $\mathrm{M}_{\text {room }}-$ room volume $\left[\mathrm{m}^{3}\right]$

n8: $\mathrm{W}_{\text {wood }}-$ coefficient of air permeability through external woodwork per range $\left[\mathrm{m}^{3} / \mathrm{m} . \mathrm{h} \mathrm{daPa}{ }^{0,7}\right]$;

and neurons in a hidden layer are $\mathrm{n} 1, \mathrm{n} 2, \mathrm{n} 3$ and $\mathrm{n} 4$ and the interpretation of the above network architecture may be as follows: neuron 1 in the hidden layer represents wind velocity, neuron 2 represents static pressure value, neuron 3 represents weighted total of pressure values, and neuron 4 takes into account length of gaps in woodwork, connections between neurons reflect mutual effects between particular factors and on final result of multiplicity of air exchange in a room.

output neuron : $\mathrm{C}_{\text {room }}-$ the air change rate in room $\left[\mathrm{h}^{-1}\right]$.

2. for modelling of air change rate in a flat, neural network with:

- 11 input neurons,

- 5 neurons of hidden layer

- 1 neuron of output layer.

Connection diagram of the above network may be illustrated as follows (Fig 2):

where neurons in an input layer are:

$\mathrm{n} 1: \mathrm{A}_{\text {wind }}$ - angle of wind arrival in relation to room wall $\left[{ }^{\circ}\right]$

$\mathrm{n} 2: \mathrm{T}_{\mathrm{dif}}-$ difference between external and internal temp $\left[{ }^{\circ} \mathrm{C}\right]$

n3: $\quad V_{\text {vent }}-$ wind velocity $[\mathrm{m} / \mathrm{s}]$

n4: $\mathrm{P}_{\text {dif }}$ - difference - external and internal pressure $[\mathrm{Pa}]$ 


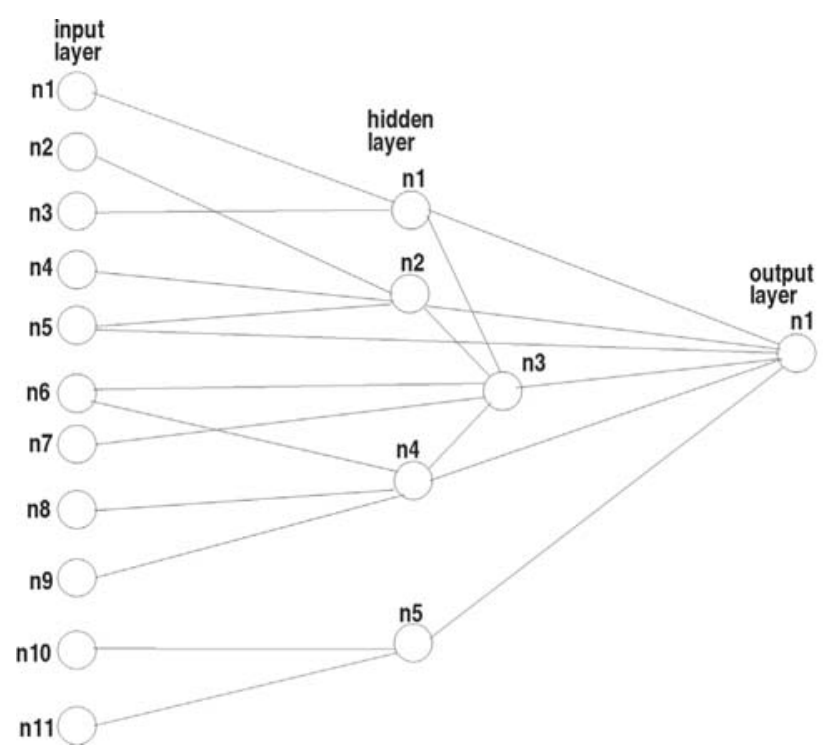

Fig 2. Connection diagram of neural networks for modelling the air change rate in a flat

$\mathrm{n} 5: \quad \mathrm{L}_{\mathrm{k}} \quad-$ numb of floor of measurement [non-dimensional] n6: $\mathrm{W}_{\text {wood }}$ - coefficient of air permeability through external woodwork per range $\left[\mathrm{m}^{3} / \mathrm{m} \cdot \mathrm{h} \mathrm{daPa}^{0,7}\right]$ :

$\mathrm{n} 7: \mathrm{R}_{\mathrm{r}} \quad$ - layout of rooms in flat (1 - facing in one direction, 2 - facing in two directions etc) [non-dimensional]

n8: $\mathrm{N}_{\text {vent }}$ - number of ventilation ducts in flat [non-dimensional]

n9: $I_{\text {gapfl }}$ - quotient of total length of gaps in external woodwork and volume of flat $\left[\mathrm{m} / \mathrm{m}^{3}\right]$

n10: $\mathrm{M}_{\text {flat }}$ - volume of the whole flat $\left[\mathrm{m}^{3}\right]$

$\mathrm{n} 11: \mathrm{W}_{\text {gapfl }}$ - coefficient of air permeability through flat access door per range $\left[\mathrm{m}^{3} / \mathrm{m} . \mathrm{h} \mathrm{daPa} a^{0,7}\right]$;

and neurons in a hidden layer are n1, n2, n3 and n4 and the interpretation of the above network architecture may be as follows: neuron 1 in the hidden layer represents wind pressure value, neuron 2 - static pressure value, neuron 3 - weighted total of pressure values, neuron 4 takes into account the length of gaps in a flat (woodwork, ducts), neuron 5 takes into account exchange value through the access door to the total volume, connections between neurons reflect mutual effects between particular factors and on final result of the air change rate in a flat.

Output neuron: $\mathrm{C}_{\text {flat }}-$ the air change rate in flat $\left[\mathrm{h}^{-1}\right]$.

The last issue remaining during the construction of neural model is the problem of recurrence of training sequence to be exposed to the neural network. In the presented study on the construction of neural model of air change rate, the appropriate trials of 2000, 5000, $10000,25000,50$ 000, 75 000, 100000 cycles were carried out.

After 100000 training cycles, the neural network for modelling the air change rate reached the point at which there was no improvement in output value. Fur- ther testing on the cycle number influence by increasing the number of training cycles indicated that during the training process, the network oscillated between the values of two minimums that were very close to each other. On the calculations of accuracy and compatibility of the results obtained, the number of 100 thousand cycles seemed to be optimal and further testing was carried out on the basis of that number of recurrence of training cycles.

The constructed neural models for determining the air change rate in a room and in a flat were subjected to verification process. The verification of models was carried out using the data from field measurement. Field measurement conditions are described more detailed in [16]. The verification was carried out on the basis of mean square deviations of the values obtained from the model in relation to the measuring values. The results obtained are presented in the Table 1 and in the form of graphs in Fig 3, Fig 4 and Fig 5 in further parts of this paper.

Table 1. Verification results for different types of buildings

\begin{tabular}{c|c}
\hline Variant & Mean square deviation \\
\hline 11-floor room & $14,1 \%$ \\
\hline 5-floor room & $13,3 \%$ \\
\hline 2-flloor room & $11,9 \%$ \\
\hline 11-floor flat & $17,2 \%$ \\
\hline 5-floor flat & $15,3 \%$ \\
\hline 2-floor flat & $13,9 \%$ \\
\hline
\end{tabular}

Example set of measuring values and values determined by the neural model of the proposed structure is presented in the form of graphs. The graph diagonal illustrates $100 \%$ compatibility between the values obtained by the neural model and those collected from measurements. As seen in the graphs (Fig 3, Fig 4 and Fig 5), the compatibility of results obtained is very high. At higher values of exchange multiplicity, there is a fixed error between the model and measuring values.

As seen from the trend line drawn on the graph, it is easy to eliminate through a correction factor to be determined from the difference between the trend line and the value of $y=x$.

\section{Conclusions}

It seems that neural networks approach to the problems of finding the air change rate for a room and for a flat gives quite good results and could be used in the decision support models for analysis of buildings behaviour. In some following studies the authors will use this approach for determining the buildings possibility to minimise energy consumption. Mean square deviations below $15 \%$ that occured in the presented models are very good results fulfilling the requirement for decision making model to describe the phenomenon nature in a generalised way. 


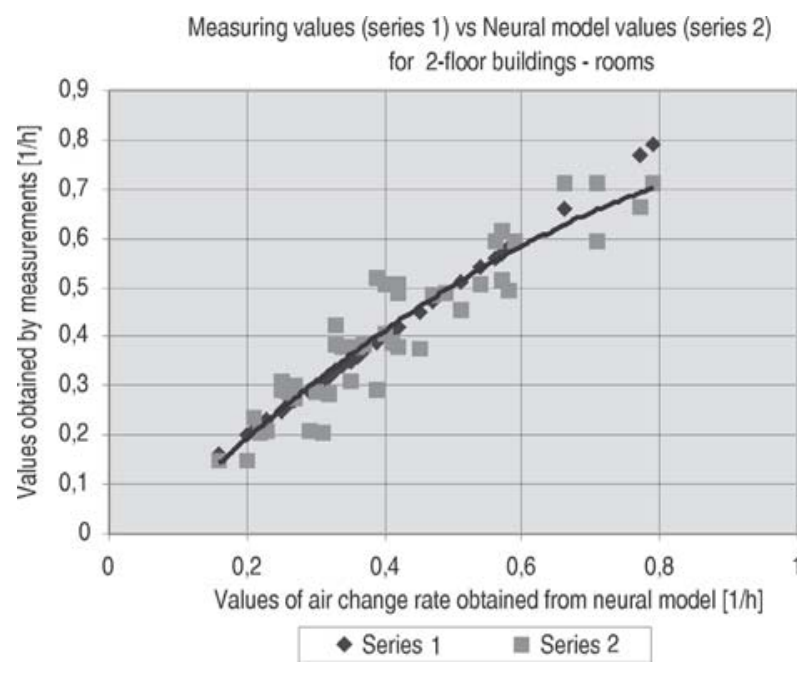

Fig 3. Measuring values versus neural model values for 2-floor buildings for the air change rate in room

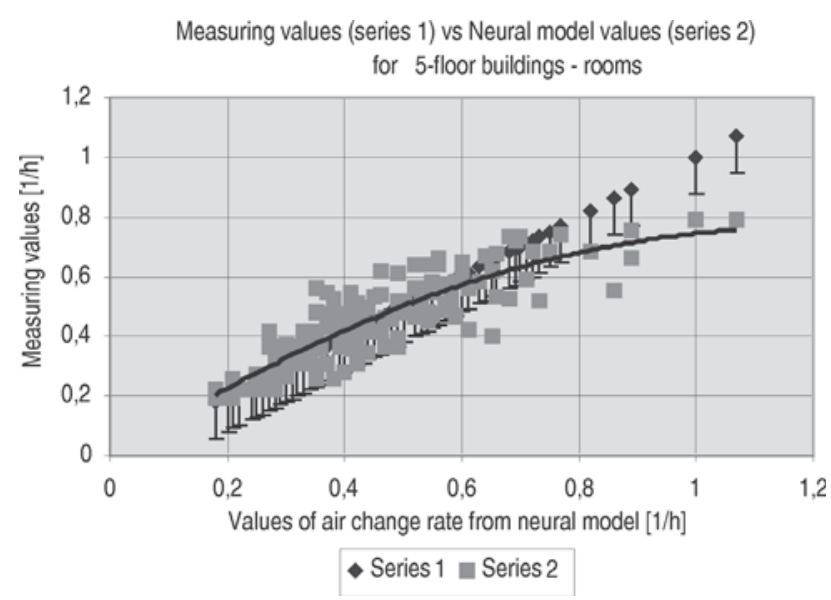

Fig 4. Measuring values vs neural model values for 5-floor buildings for the air change rate in room

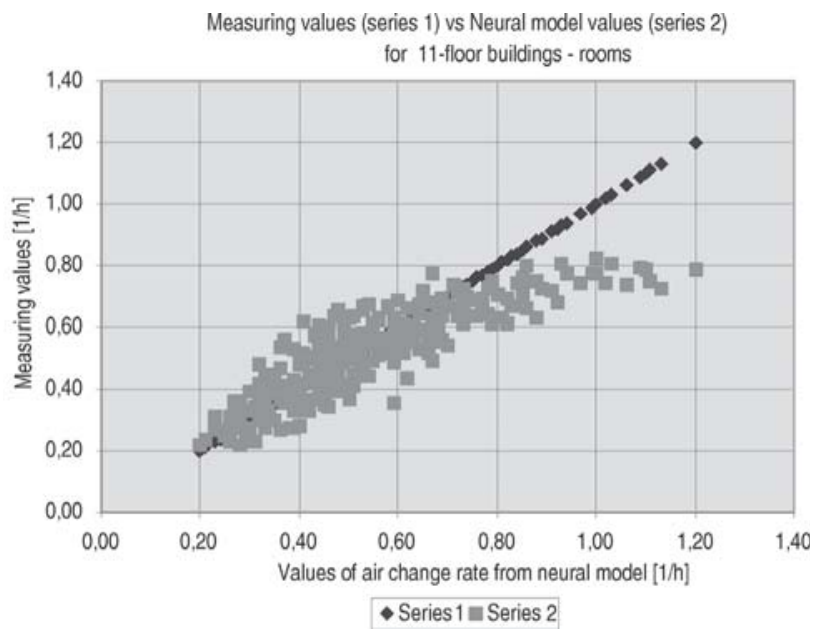

Fig 5. Measuring values vs neural model values for 11 -floor buildings for the air change rate in room
It also must be remembered that in such an issue as modelling (air change rate in a room or flat), too precise model is certainly not a desired model, because there is a high probability of loosing the nature of the whole phenomenon and constructing the model of specific room or flat instead of general phenomena.

\section{References}

1. Miller, W.; Sutton, R.; Werbos, P. Neural networks for control. Cambridge MA, MIT Press, 1990. 210 p.

2. Hunt, K.; Sbarbaro, D.; Zbikowski, R. Neural networks for control systems. A survey. Automatica, Vol 28, Issue 6, 1992, p. 1083-1112.

3. IEEE, Special issue on neural networks, IEEE Control Systems Magazine, Vol 8, Issue 2, 1988, p. 3-88.

4. IEEE, Special issue on neural networks, IEEE Control Systems Magazine, Vol 9, Issue 3, 1989, p. 4-86.

5. IEEE, Special issue on neural networks, IEEE Control Systems Magazine, Vol 10, Issue 3, 1990, p. 6-125.

6. IEEE, Special issue on neural networks, IEEE Control Systems Magazine, Vol 12, Issue 2, 1992, p. 19-94.

7. Eykhoff, P. Trends and progress in system identification. Oxford: Pergamon Press, 1981. 402 p.

8. Singh, M.; Titli, A. Systems: decomposition, optimization and control. New York: Pergamon Press, 1978. 296 p.

9. Narendra, K.; Annaswamy, A. Stable adaptive system. Englewood Cliffs, New Jersey: Prentice Hall, 1989. 496 p.

10. Kaczorek, T. Theory of controls and systems (Teoria systemów sterowania i kontroli). Warsaw, Poland, PWN, 1993. 801 p. (in Polish).

11. Korbicz, J.; Mazurkiewicz, Z.; Janczak, A. Chosen problems of identification and estimation (Wybrane problemy identyfikacji i estymacji). Zielona Góra, Poland. WSInz., 1987. 144 p. (in Polish).

12. Goldberger, A. Theory of econometry (Teoria ekonometrii). PWN, Warsaw. Poland, 1975. 503 p. (in Polish).

13. Tadeusiewicz, R. Neural networks (Sieci neuronowe). Warsaw, Poland. Akademicka Oficyna Wydawnicza RM, 1993. 256 p. (in Polish).

14. Korbicz, J.; Obuchowicz, A.; Uciński, D. Artificial neural networks. Basic concepts and implementations (Sztuczne sieci neuronowe. Podstawy i zastosowania). Warsaw, Poland. Akademicka Oficyna Wydawnicza, 1994. 251 p. (in Polish).

15. Narendra, K.; Parthasarathy, K. Identification and control of dynamical systems using neural networks. IEEE Transactions on Neural Networks, Vol 1, Issue 1, 1990, p. 4-27.

16. Mańczak, K.; Nahorski, Z. Computer identification of dynamic objects (Komputerowa identyfikacja obiektów). Warsaw, Poland. PWN, 1983. 432 p. (in Polish).

17. Tiguni, Y.; Sakai, H.; Tokumaru, H. A nonlinear regulator design in the presence of system uncertainties using multilayered neural networks. IEEE Transactions on Neural Networks, Vol 2, Issue 4, 1991, p. 410-417.

18. Nguyen, D.; Widrow, B. Neural networks for self-learning control systems, IEEE Control Systems Magazine, Vol 10, Issue 3, 1990, p. 18-23. 
19. Faryniak, L.; Pająk, P.; Piotrowski, J. Z. Implementation of neural networks to the problems of air-change rate in rooms (Zastosowanie sieci neuronowych do problematyki wymiany powietrza w pomieszczeniach). In: XLIII Conference of Civil Engineering of PAN, Poznań-Krynica, Poland. Part 6, 1997, p. 129-134 (in Polish).

\section{NEURONINIS INFILTRACIJOS PROCESO GYVENAMAJAME NAME MODELIS}

\section{P. Malinowski, I. Polarczyk, J. Piotrowski}

\section{Santrauka}

Šiam straipsniui pasirinkti aspektai, susiję su infiltracijos procesu ir neuroniniais tinklais. Infiltracijos pastatuose matavimai parodè, koks sudètingas yra griežtas matematinis šio proceso modeliavimas. Analizuojant infiltracijos procesą neuroninių tinklų požiūriu, dèmesys buvo skiriamas daugiasluoksniams perceptronams ir iš jų sudarytoms sistemoms. Atsižvelgiant i šio metodo naujumą, straipsnyje pateikiamas tiek neuronų tinklo teorijos, tiek išsamus neuroninio modeliavimo proceso aprašymas. Darbas buvo atliktas dviem etapais: pirmajame sukurta neuroninio modelio sudarymo metodika, antrajame ši metodika buvo pritaikyta realiems objektams modeliuoti.

Raktažodžiai: infiltracijos procesas, neuroniniai tinklai, neuroniniai modeliai.

Pawel MALINOWSKI. Doctor working since 1991 at the Wrocław University of Technology, Poland. Adjunct at the District Heating and Ventilation Chamber. Teaching subjects: energy, energy systems, natural gas and domestic water systems and instalations, as well as modelling, mathemathical modelling, data analysis, control systems. Research in different domains such as: optimisation of energy systems, analysis of monitoring data, neural networks and fuzzy logic models of air-pollutants movment. Published about 70 papers. Research interest is focused on applying the computer science methods to modelling the energy systems.

Iwona POLARCZYK. Doctor working at the District Heating and Ventilation Chamber of Wrocław University of Technology, Poland. Her PhD in 2002 on heating of big-volume buildings. Her research interest is focused on domestic hot water systems and ventilation as well as heating of buildings. Author and co-author of about 30 papers in those research areas.

Jerzy PIOTROWSKI. Professor at Swietokrzyski University of Technology, Kielce, Poland. His work at the Civil Engineering Dept and his research interests are focused on building physics, climate of rooms, air change in buildings, ventilation and neural networks modelling. An active engineer, the author of more than 300 expert reports, 50 publications and 2 monographs. 